Global Conferences Series:

Social Sciences, Education and Humanities (GCSSSEH), Volume 3, 2019

The $1^{\text {st }}$ International Conference on Education, Social Sciences and Humanities

DOI: https://doi.org/10.326/hum0206

\title{
The development of Science learning module use the Learning Cycle 5E for Elementary School student
}

\author{
Ali Imran ${ }^{1}$, Risda Amini ${ }^{2}$, Aliasar ${ }^{3}$ \\ 1,2,3 Universitas Negeri Padang, Indonesia \\ ali.imran822@yahoo.com
}

\begin{abstract}
Abstrak
Teaching materials used have not led students to develop concepts that have been learned to discover new knowledge themselves. Overcoming this, a solution is needed to develop a science learning module use the learning cycle type 5E. The purpose of this research is to produce a science learning module use the learning cycle type 5E. The development model used $4 \mathrm{D}$ model that consist of define, design, develop, and disseminate. The research instrument were validition sheet, questionnaire, learning outcome test. The result that the science learning module include the valid category. The science learning module was include the practical category. The use of science learning module can improve the students' learning outcome and activity. This means that science learning module effective to increase the activities and learning outcome of students at Elementary School.
\end{abstract}

Key words: Science learning module, Learning Cycle 5E

\section{Introduction}

Natural Science (IPA) is a science group that has special characteristics, namely studying factual natural phenomena, whether in the form of reality or event and consequent relationship. Natural Science (IPA) is related to how to find out about nature systematically, so that science is not only mastery of a collection of knowledge in the form of facts, concepts, or principles but also is a process of discovery. Science education is expected to be a vehicle for students to learn about themselves and their surroundings, as well as the prospects for further development in applying them in their daily lives. The learning process emphasizes providing direct experience to develop competencies in order to explore and understand the natural environment scientifically. Science education is directed towards inquiry so that it can help students to gain a deeper understanding of the environment (BSNP, 2006).

Based on the Regulation of the Minister of National Education Number 22-23 of 2006 concerning the Standards of Content (SI) and Graduates' Competency Standards (SKL), the Education Unit Level Curriculum (KTSP) was established as a curriculum in education in Indonesia. KTSP is a manifestation of a competency-based curriculum. KTSP demands that learning be done in a constructivist, contextual and student center. In order for science concepts

Copyright $(\odot$ 2019, the Authors. Published by Redwhite Press.

Page | 122

This is an open access article under the CC BY-NC license

(http://creativecommons.org/licenses/by-nc/4.0). 
to be understood properly and correctly by students, science teaching must be focused on the role of students actively.

The implementation of current learning is mostly done in a classical manner where all students are considered the same in all respects both ability, learning style, speed of understanding, motivation to learn and so on; even though the characteristics of students differ from one student to another. In principle the purpose of learning is so that students succeed in mastering the subject matter in accordance with predetermined indicators. Learning that is done must be able to develop the ability of students to find concepts that have been learned and develop new concepts in relation to everyday life. So that students can build their own knowledge and put it in daily life. One way that is quite relevant to solving these problems is the application of individual learning, which gives credence to the individual's ability to learn independently. One individual learning model is a module learning system (Wena, 2009: 224).

According to Russell (1974) the module learning system will make learning more efficient, effective and relevant. Modules are a set of stand-alone learning experiences that are used to make it easier for students to reach a set of set goals. Modules are a gift of written learning material that can be learned by students with their autoactivity, where teacher services and guidance are arranged as little as possible (Soemirat, 1980: 3). One model developed in constructivist learning is the Learning Cycle 5E Model. This learning model suggests that the learning process involves students in active learning activities resulting in the process of assimilation, accommodation, and organization in cognitive structures (equilibration). In this case learning is interpreted as a result of the interaction of individuals with the environment. The learning cycle 5E model connects students' initial knowledge to form new knowledge through several stages or phases namely engagement (arousing interest and sense of curiosity), exploration (exploration), explanation (explanation of concepts), elaboration (application of concepts), and evaluation (evaluation). For this reason researchers want to develop learning using science learning modules using the $5 \mathrm{E}$ learning cycle model (Learning Cycle 5E).

Based on the background above, the researcher chose the title "Development of a science learning module using the 5E Elementary Learning Cycle".

\section{Method}

This type of research is development research that aims to develop teaching materials that are valid, practical, and effective. Research and development method is research that aims to produce certain products and test the effectiveness of these products (Sugiyono, 2015: 87). The purpose of development research in education is not to formulate or test theories but develop effective products that will be used in elementary schools.

The development model used is a 4-D model, developed by S. Thiagarajan, (in Trianto 2012: 189) this model consists of four stages, namely defining, designing, developing and distributing ( disseminate). (1) define, at the defining stage there are three steps taken, namely: curriculum analysis (KTSP), needs analysis, student characteristics analysis. (2) design (design), the design phase aims to design the learning module. There are three phases of activity at this stage: compiling benchmark reference tests, media selection, format selection. (3) developing stages to produce products that are carried out through two steps, namely: expert assessment followed by revision and trial development. The purpose of this stage is to produce a learning module that is valid, practical, and effective. (4) disseminate this stage of the learning module developed in other subjects, the purpose of which is to test the effectiveness of using the learning module on different objects. 
The products that have been produced are limited trials. The test subjects in this study were the fifth grade students of SD Negeri 06 Hulu Banda, Malalak District, Agam Regency, 20 students and the distribution was carried out on students of SD Negeri 08 Salimpaung, Malalak District, Agam Regency with 15 students.

The instrument of data collection in this development research was a questionnaire (questionnaire). Questionnaires (questionnaires) are used to obtain data on the validity, effectiveness and practicality of the textbooks. The research instruments developed for data collection in this study were validation instruments, practicality instruments, and instruments of effectiveness. The analysis technique used in the study is descriptive data analysis, which describes the validity level of the science learning module using the cycle $5 \mathrm{E}$, the practicality of textbooks, and student competencies that show the effectiveness of the science learning module using the learning cycle5E.

\section{Results And Discussion}

The product of the design is a science learning module using a learning cycle 5E consisting of 3 parts, namely 1) Pre-introduction, consisting of cover, introduction, module usage instructions, and table of contents. 2) Introduction contains a curriculum that includes Competency Standards (SK), Basic Competencies (KD), and indicators of achievement of learning outcomes. 3) Learning activities include learning activities about the characteristics of light, where each learning activity consists of five phases, namely the introduction phase, exploration phase, explanation phase, elaboration phase, and evaluation phase (evaluation). Furthermore, there are materials, summaries, formative tests, feedback, and answer keys. In the third step, the development of the initial product draft is carried out by reviewing the module, syllabus and lesson plan to the validator. From the results of the study it was obtained input and suggestions which were then revised. A summary of the data from the module validation as a whole is found in the table.

Table 1. Results of Questionnaire Analysis of Science Module Validation Using the 5E Learning Cycle

\begin{tabular}{clcl}
\hline No & Assessment Aspect & Value of Validity & Category \\
\hline 1. & Feasibility of content and presentation & 3,88 & Very Valid \\
\hline 2. & Language feasibility & 3,76 & Very valid \\
\hline 3. & Feasibility of graphics & 3,84 & Very Valid \\
\hline \multicolumn{2}{r}{ Rata-rata } & 3,83 & Very Valid \\
\hline
\end{tabular}

After the Science Learning Module using the learning cycle 5E is declared valid, the next step is to conduct a trial to find out the practicality and effectiveness of the science learning module developed. The trial was conducted on fifth grade students of SD Negeri 06 Hulu Banda Malalak District, Agam Regency. The trial was conducted for 3 meetings on the material properties of light.

The practicality of the science learning module developed can be seen from the observation sheet of the implementation of learning, the results of the practical questionnaire analysis by teachers and students, observing the use of the Science Learning module by students. 
Table 2 Results of Observation on the Implementation of RPP

\begin{tabular}{ccccc}
\hline \multirow{2}{*}{ Learning } & \multicolumn{3}{c}{ Observer Assessment } & \\
& Percentage & Average & Category \\
\cline { 2 - 3 } & O1 & O2 & & \\
\hline I & 3.54 & 3,56 & 3.55 & Practical \\
\hline II & 3.72 & 3,78 & 3.75 & Practical \\
\hline III & 3,89 & 3,89 & 3.89 & Practical \\
\hline Practical Level of Implementation of RPP & 3.70 & Practical \\
\hline
\end{tabular}

Data analysis was obtained from each teacher's questionnaire response to the practicality of the Science Learning module can be seen in table 3 below.

Table 3. Results of Teacher Response Questionnaire Analysis

\begin{tabular}{lcc}
\hline Results & Average & Category \\
Teacher 1 & 88.9 & Very practical \\
Teacher 2 & 85.1 & Very practical \\
\hline
\end{tabular}

Questionnaire for students' responses is given to find out the opinions of students about the practicality of the Science Learning module. The results of the student response questionnaire after using the Science Learning module can be seen in the table below.

Table 4. Results of Practicality Questionnaire for Students

\begin{tabular}{clll}
\hline Results & Amount & Average & Category \\
\hline $\begin{array}{l}\text { Questionnaire for student } \\
\text { responses }\end{array}$ & 909,76 & 82,71 & Very practical \\
\hline
\end{tabular}

Student activities during the learning activities take place are observed by using student activity observation instruments. The average observation of student activities can be seen in table 5 below.

Table 5. Average Observation Results of Student Activities During Trial and Distribution

\begin{tabular}{lll}
\hline Results & Average & Category \\
\hline Trials & 81,15 & Very active \\
\hline Spread & 82,22 & Very active \\
\hline
\end{tabular}

Another component used to determine the effectiveness of the Science Learning module developed is by evaluating student learning outcomes from aspects of attitudes, knowledge and skills. The results of the assessment data during the learning process can be seen in table 6 below.

Table 6. Average Student Learning Outcomes in Trials and Spreads

\begin{tabular}{ccccc}
\hline Hasil & Pengetahuan & Sikap & Keterampilan & Kategori \\
\hline Uji coba & 90,21 & 83,65 & 85,66 & Sangat baik \\
\hline Penyebaran & 88,12 & 86,25 & 85,95 & Sangat baik \\
\hline
\end{tabular}

Based on table 6, student learning outcomes from 3 aspects obtain a very good category. This indicates that the Science Learning module using the learning cycle 5E that was developed was effectively used.

\section{Conclusion}

Based on the results of research data analysis and discussion it can be concluded that:

1. The science learning module uses the learning cycle 5E developed consisting of 5 phases, namely the engagement phase, exploration phase, explanation phase (explanation phase), 
concept implementation phase (elaboration) and evaluation phase (evaluation). The results of module validation developed obtained an average of 3.83 with very valid criteria. In the practicality stage, the results obtained are 3.70 with very practical criteria), the value of the effectiveness of the learning module is 3.62 Criteria are very good. The level of completeness of student learning outcomes reaches $87 \%$.

2. Students' responses to learning using science learning modules using the $5 \mathrm{E}$ learning cycle are generally very good, so it can be said that the modules developed are feasible to use.

Based on the results of the study, there are several suggestions as follows:

1. The researcher suggests optimizing the atmosphere and good learning cycle so that the planned learning goals are achieved optimally.

2. The use of science learning modules using learning classes $5 \mathrm{E}$ as one of the teaching materials that can improve student learning outcomes

3. Development of science learning modules using $5 \mathrm{E}$ learning cycles can be developed more widely in other learning materials.

\section{References}

Amini, R. (2015). Pengembangan Model Pembelajaran Konsep Ipa SD Berbasis Kegiatan Laboratorium Menggunakan Pendekatan SAVI. , 1201.

Amini, R. (2015). Pengembangan Model Pembelajaran Konsep Dasar Ipa Sd Menggunakan Pendekatan SAVI. Pedagogi: Jurnal Ilmu Pendidikan, 15(1), pp.34-39.

Amini, R., (2017). The Development Of Integrated Learning Based Students'book To Improve Elementary School Students' competence. Unnes Science Education Journal, 6(2)

Eisenkraft,A.(2003). Expanding the 5E Model Apurposed 7E model emphasizes"transfer of learning" and the inportance of eliciting prior understanding. Published by the national science teachers Association, 1840 Wilson Blvd. Arlington, VA 22201-3000

Hasret,N. Dan Yalcin,N.(2006) The Effectiviness of The Learning Cycle Model to increase Students Achievemen in the Physics Laboratory. Journal of Turkish Science Education. 3,issue2.

Netti,F.,Usmeldi.\& Yulkifli (2012). Upaya Peningkatan Kompetensi Afektif Peserta Didik Dalam Pembelajaran Fisika Dengan Menerapkan Model Learning Cycle 5e Di Kelas IX.2 Smp Negeri 2 Candung. Scholary Jurnal, vol. 1, no.1.

Rodger, Dkk. (2006). The BSCS 5E Instructional Model: Origins, Effectiveness, and Applications. http://www.bscs.org/sites/default/files legacy/BSCS 5E Instructional ModelExecutive Summary 0.pdf diunduh tanggal 30 juni 2017)

Salih C, Cigdem,S. \& Hava. (2010). Teaching floating and sinking concepts with different Methods and tecnigues based on the 5E intructional model. Asia Facific Forum on Science Learning and Teaching.

Sugiyono. (2009). Metode Penelitian Pendidikan Pendekatan Kuantitatif, Kualitatif, dan R\&D. Bandung: Alfabeta

Trianto. (2010). Pengantar Penelitian Pendidikan bagi Pengembangan Profesi Pendidikan dan Tenaga Kependidikan. Surabaya: Prenada Media Group.

Trianto. (2012). Mendesain Model-Model Pembelajaran Inovatif-Progresif. Jakarta: Kencana.

Wena, M. (2009). Strategi Pembelajran Inovatif Kontenporer. Jakarta: Bumi Aksara. 